\title{
Work/Family Policies in Higher Education: Survey Data and Case Studies of Policy Implementation
}

\author{
Carol S. Hollenshead, Beth Sullivan, Gilia C. Smith, \\ Louise August, Susan Hamilton
}

Today's American families face a juggling act of home and work, school, medical care, after-school activities, and other responsibilities required to raise a family and maintain a household. Studies produced by advocates in the nonprofit sector indicate the need for improved family leave benefits and document substantial interest in the area by policymakers at the state level (Holcomb, 2001).

Since the empowerment of the employee at the organizational level and the move from standardization to flexibility is an essential part of the new postmodern and postbureaucratic organization (Kumar, 1995), employers across the country have begun to respond to this new philosophy. Increasingly employers have developed policies that acknowledge the need for a healthy balance between work and home. In fact, more than one-third of American companies now offer maternity leave in excess of that guaranteed by the Family and Medical Leave Act (FMLA), and another 15 percent offer the same leave to new fathers, adoptive parents, or employees with sick dependents (Holcomb, 2001). These policies allow employees greater flexibility in the way they use their sick time, schedule their work hours, fulfill their duties, and interweave pregnancy, childbirth, and parenting with careers. Studies in the corporate sector have demonstrated that better work/family balance ultimately leads to improvements in employee morale (Galinsky, Friedman, and Hernandez, 1991) and is increasingly viewed by managers in both the corporate and nonprofit sectors as cost effective. 
But to what degree do institutions of higher education have such policies in place for their faculty? In 2001, the American Association of University Professors (AAUP) declared that "the development and implementation of institutional policies that enable the healthy integration of work responsibilities with family life in academe requires renewed attention." A 1996 study conducted by the Foundation of the College and University Personnel Association and the Families and Work Institute provides helpful answers to some of these questions. The College and University Reference Guide to Work/Family Programs offers a snapshot of the policies and programs available to faculty and staff in the mid-1990s (Friedman, Rimsky, and Johnson, 1996). This study took the important first step of surveying a broad array of policy and program options in existence at American institutions.

In recent years, a number of studies documenting and analyzing the use of work/family policies in academic institutions have examined the variety of methods institutions use to help faculty balance their responsibilities to work and to families. Policies most frequently researched include those allowing faculty to stop the tenure clock (American Association of University Professors, 2001; Wilson, 2001), work part time (Drago and Williams, 2000; Leslie and Walke, 2001), or negotiate with department chairs to modify job duties (Cramer and Boyd, 1995). Parental leave policies for child care or elder care and policies supporting dual-career couples are also frequently discussed. In addition, current research documents the institutional costs of not accommodating family caregiving and barriers to the implementation and utilization of work/family policies in academic institutions (Friedman, Rimsky, and Johnson, 1996).

Theoretical and descriptive studies link the limited availability of work/family policies to the slow improvement of women's status within the professoriate (AAUP, 2001; Drago and Williams, 2000). Although the number of women in academia continues to increase, women are disproportionately represented in non-tenure-track positions, at nondoctoral institutions, and among low salary grades (AAUP, 2001; Glazer-Raymo, 1999; Rhoads and Rhoads, 2003; Hollenshead and others, 2003). Moreover, tenured and tenuretrack women are less likely to have children than tenured and tenure-track men (Mason and Goulden, 2002). Researchers concur that the model academic career path and tenure system often conflicts with a faculty member's familial responsibilities. Women continue to perform the majority of caregiving tasks in most U.S. families and are thus disproportionately affected by conflicts between the ideal academic career trajectory and family needs (Hochschild, 1989; Drago and Williams, 2000). Nevertheless, there has been increased interest in developing policies that are available to men.

The research on work/family policies in institutions of higher education is conducted by investigators from a variety of fields, including higher education, organizational theory, social work, women's studies, labor studies, family studies, and psychology. Methodologies range from quantitative national surveys to historical and theoretical contextual studies. This lack 
of homogeneity in research methods is matched to some extent by the divergent organizational systems and political climates of the universities being studied.

Many work/family policies are implemented in varying ways within institutions, often on a case-by-case basis, making data collection challenging. Thus, it is unclear if and how various institutions implement work/ family policies or how such policies are received and used by faculty. In order to help fill this gap, we studied the policies of a cross-section of universities and examined in detail in a smaller number of institutions how those policies were developed, used, and perceived.

\section{The Faculty Work/Family Policy Study}

The Faculty Work/Family Policy Study, undertaken by the University of Michigan's Center for the Education of Women, analyzed policies and programs from a large, representative sample of U.S. institutions stratified by Carnegie classification. Funded by the Alfred P. Sloan Foundation, the study included a Web-based survey of 648 universities and colleges, of which 255 (39 percent) responded. This was followed by a telephone survey of 51 of those respondents. The study delved into questions regarding the development, administration, and use of faculty work/family policies in an attempt to address the following questions:

- Do work/family policies for faculty vary by the Carnegie classification of the institution, or are certain policies becoming the norm?

- Are policies based on written, formal policy or on informal practice?

- What are the eligibility and entitlement criteria for these policies?

- What barriers exist to the creation of family-friendly policies? What types of environments facilitate their implementation?

- To what extent are work/family policies used by faculty? If the rate of use is particularly low or high, why might that be?

The study revealed some interesting findings on these points, which are detailed later in the chapter. The work/family policies examined were tenure clock stop, modified duties, paid leave while recovering from childbirth, paid dependent care leave, unpaid dependent care leave in excess of the twelve weeks mandated by FMLA, reduced appointments for ordinary or extraordinary dependent care needs, and the availability of part-time and job-share appointments. In addition, the study probed the existence of individuals or units designated to assist faculty with work/family issues, as well as employment assistance to spouses or partners of faculty.

We recognize that a good deal of policy implementation, especially when informal practice is considered, is decided at the unit level within colleges. However, this study chose to take an institution-wide view to various aspects of policy development, administration and use. 


\section{Work/Family Policies and Programs Defined}

While the meaning behind some policies or programs is self-evident by their name, other work/family initiatives are not as clearly understood. For this reason, we briefly review the meanings of key policies and programs studied.

Tenure Clock Stop. Of the policies examined, the one most commonly provided was tenure clock stop. Tenure clock stop policies allow a tenure-track faculty member to have a temporary pause in the tenure clock to accommodate special circumstances. At the end of such a pause, the clock resumes ticking with the same number of years left to tenure review as when it paused. Circumstances occasioning the use of this policy include birth or adoption of a child, serious medical illness of the faculty member, or extensive care needs by a dependent of the faculty member. This policy is also sometimes referred to as a tenure clock extension.

While most colleges that have a tenure clock stop policy make this policy available to both men and women faculty, women's greater need for this policy should be noted. Since the timing of the tenure process tends to overlap with the childbearing years, the pursuit of tenure often conflicts with a woman's decision to have children. It has been suggested that use of a pause in the tenure clock allows women faculty to adjust better to the demands of a new infant without permanently derailing their careers.

Modified Duties. Modified duties policies allow a faculty member to reduce her or his teaching, research, or service load for a temporary period (usually a term or two) without a commensurate reduction in pay. Teaching demands often make it difficult for faculty members to use traditional sick or disability leaves. Therefore, modified duties policies provide a method for responding to the needs of faculty caring for infants, elders, or critically ill spouses or partners. For women faculty who are recovering from childbirth, a modified duties policy may be seen as equivalent to the six to eight weeks of full-time paid sick leave most universities offer women in staff positions.

Paid Leave to Recover from Childbirth. Because leaves for women recovering from childbirth can fall under many different names, our survey asked how institutions provided paid time off for faculty women who are pregnant or recuperating from childbirth. It was important to separate this leave from dependent care leave, which does not involve physical recovery of the faculty member but is simply designed to allow care for another individual.

Paid Dependent Care Leave. The variety of dependent care leaves is more complex than one might expect. Examples of dependent care leave for infant care include parental leave, maternity or paternity leave, and adoptive parent leave. Many colleges that have such dependent care leaves also include care for ailing parents, spouses, or partners.

Unpaid Dependent Care Leave. The FMLA establishes that employers with fifty or more employees must allow up to twelve weeks of unpaid leave in order to care for a newly born, adopted, or fostered child; receive care for a serious health condition; or assist a family member who is receiving such care. Federal rules list a number of individuals who meet 
the definition of a "qualified family member." While FMLA rules do not consider parents-in-law, significant others, and domestic partners as qualified family members, employers are free to include additional categories of individuals under an expanded definition of "qualified family member" if the employer so chooses. For the purposes of this study, the term dependent referred to individuals such as young children; disabled adult children; elderly, ill, or disabled parents or siblings; and ill, injured, or disabled spouses or partners.

Reduced, Part-Time, and Job-Share Appointments. Reduced, parttime, or job-share appointments are defined as those in which a faculty member works less than 100 percent for the institution. For the purposes of this study, the distinction was made between part-time appointments from the date of hire and reduced appointments, in which full-time appointments were reduced to part time after the date of hire. For these appointments, pay is proportionate to the percentage of effort reflected by the appointment. Split appointments (those involving two units of the same institution) were not defined as part-time, reduced, or job-share appointments for the purposes of this study.

In the Web-based survey, we differentiated between reduced appointments for extraordinary reasons (for example, to care for an injured child, spouse, or partner) and reduced appointments for ordinary reasons (for example, to spend more time at home with young children or as a shortterm transition from maternity leave).

Job-share policies allow two faculty members to each work part-time while fulfilling, between them, the requirements of one full-time faculty position.

Staff Assistance with Work/Family Policies and Employment of Spouses or Partners. One of the measures on our survey was a dichotomous variable indicating the presence (or absence) of units or personnel clearly assigned to advise faculty regarding availability and implementation of work/family balance policies. The survey also measured whether institutions provided employment assistance (such as help in job searches or job placement) for partners or spouses of faculty. These programs are sometimes referred to as dual-career hiring or trailing-spouse programs.

\section{Methodology}

The study used two instruments: an initial Web survey and a follow-up telephone survey. The process for collection of survey data began with identification of a contact person at each institution who was knowledgeable and willing to return the requested survey information. Researchers called the executive officer in charge of academic affairs and requested to speak with someone knowledgeable regarding faculty policies. This contact (usually from the office of academic affairs, human resources, or institutional research) was asked to complete and submit a short Web-based survey. A paper version was also available. 
Table 3.1. Description of the Sample

\begin{tabular}{lccccccc}
\hline & $\begin{array}{c}\text { Research } \\
\text { I and II }\end{array}$ & $\begin{array}{c}\text { Doctoral } \\
\text { I and II }\end{array}$ & $\begin{array}{c}\text { Master's } \\
\text { I and II }\end{array}$ & $\begin{array}{c}\text { Baccalaureate } \\
\text { I and II }\end{array}$ & Associate & Total \\
\hline Number surveyed & 123 & 38 & 180 & 198 & 109 & 648 \\
Number returned & 73 & 16 & 66 & 70 & 30 & 255 \\
Response rate & $59 \%$ & $42 \%$ & $35 \%$ & $35 \%$ & $28 \%$ & $39 \%$ \\
\hline
\end{tabular}

The sample developed for the survey was a stratified random sample of 704 institutions from the 2000 Carnegie list (although using the 1994 classifications). The reason for using the 1994 rankings was to provide a finer breakdown by institutional rank than the 2000 ranking provides.

The sample strategy was to select approximately 35 percent of the institutions within each Carnegie category. Due to their small number, all research institutions were included in the sample. And due to their large numbers, a smaller fraction of Associate degree institutions were included in the sample. In addition, all institutions with membership in the College and University Work/Family Association were included in the sample, as were "leadership campuses" as defined in an earlier study (Friedman, Rimsky, and Johnson, 1996). With the exception of specialty schools in the area of technology, nine types of specialized institution categories (such as tribal colleges, free-standing law schools, and theological seminaries) were excluded. Technology schools were originally included in the sample because of their particular significance to the Sloan Foundation, funder of the research. Due to a low response rate from these schools, however, their results are not included in the analysis. From the original sample of 704 schools, the list of potential respondents was reduced to 648 , primarily due to some institutions' refusal to provide an assigned respondent for the survey.

From the 648 survey recipients, the Center for the Education of Women received 255 responses to the first stage of the study. Response rates across the sample varied by Carnegie classification (see Table 3.1). Thirty-nine percent of the sample responded to the initial Web-based survey.

\section{The Web Survey}

There were four versions of the Web-based survey: one was for institutions without tenure or identified research faculty; another was for institutions with tenure but without research faculty; a third was for institutions with both tenure and research faculty; a fourth was for institutions without tenure but with research faculty. (It should be noted, however, that although there were schools in the original sample that fell into this final category, none responded to the survey.) The contact person for each institution chose the appropriate survey. 
Table 3.2. Number of Institution-Wide Formal Policies

\begin{tabular}{|c|c|c|c|c|c|c|c|}
\hline $\begin{array}{l}\text { Number of } \\
\text { Policies }\end{array}$ & $\begin{array}{c}\text { Research } \\
\text { I and II } \\
(n=73)\end{array}$ & $\begin{array}{l}\text { Doctoral } \\
\text { I and II } \\
(n=16)\end{array}$ & $\begin{array}{c}\text { Master's } \\
\text { I and II } \\
(n=66)\end{array}$ & $\begin{array}{c}\text { Baccalaureate } \\
\text { I and II } \\
(n=70)\end{array}$ & $\begin{array}{l}\text { Associate } \\
(n=30)\end{array}$ & In & $\begin{array}{c}\text { All } \\
\text { istitutions } \\
l(n=255)\end{array}$ \\
\hline 0 & $7 \%$ & $31 \%$ & $38 \%$ & $51 \%$ & $50 \%$ & $34 \%$ & 86 \\
\hline 1 & 18 & 25 & 30 & 19 & 37 & 24 & 61 \\
\hline 2 & 22 & 25 & 14 & 13 & 7 & 16 & 42 \\
\hline 3 & 21 & 13 & 12 & 9 & 0 & 12 & 34 \\
\hline 4 & 7 & 6 & 0 & 6 & 3 & 4 & 16 \\
\hline 5 & 8 & 0 & 3 & 1 & 3 & 4 & 27 \\
\hline 6 & 18 & 0 & 2 & 1 & 0 & 6 & 10 \\
\hline 7 & 0 & 0 & 2 & 0 & 0 & 0 & 7 \\
\hline 8 & 0 & 0 & 0 & 0 & 0 & 0 & 10 \\
\hline $\begin{array}{c}\text { Average number } \\
\text { of policies }\end{array}$ & 2.99 & 1.38 & 1.29 & 1.09 & 0.80 & 1.67 & \\
\hline
\end{tabular}

${ }^{a}$ Note: The differences in the average number of policies between research institutions and all other types of institutions were statistically significant at levels of $\mathrm{p} \leq .001$ or better.

For the purposes of this study, faculty member was defined as an individual with a regular instructional appointment or anyone with a regular faculty research appointment (a researcher who can serve as a principal investigator or coprincipal investigator on a research grant and whose primary responsibility does not involve regular teaching). This definition did not include lecturers, clinical faculty, visiting, or adjunct faculty. The term dependent referred to individuals such as young children; disabled adult children; elderly, ill, or disabled parents or siblings; and ill, injured, or disabled spouses or partners.

The next several sections summarize the results of the Web survey.

Average Number of Policies Offered. Based on the survey responses, we tallied the number of work/family policies each institution had that were institution-wide and formal. On average, institutions reported having fewer than two institution-wide policies. However, research institutions reported twice as many policies as other schools in the sample. (See Table 3.2.)

We also looked separately at elite baccalaureate institutions-those named to the U.S. News and World Report list of top one hundred liberal arts colleges in the country. When we analyzed the number of policies held by institutions considered elite versus the remaining baccalaureate colleges among our respondents, we found the elite baccalaureates had 2.53 policies on average, while other baccalaureates had 0.69 policies. We surmise that elite baccalaureate colleges, in competition for faculty with research institutions, have developed a greater number of family-friendly policies as a recruitment strategy.

Policies Less Available to Research Faculty. The study sought to answer whether research faculty were eligible to use work/family policies to the same extent as tenure-track or tenured faculty. For every policy on 
Table 3.3. Formal and Informal Institution-Wide Policies by Institution Type

\begin{tabular}{|c|c|c|c|c|c|c|}
\hline & $\begin{array}{l}\text { Research } \\
I \text { and II } \\
(n=73)\end{array}$ & $\begin{array}{l}\text { Doctoral } \\
I \text { and II } \\
(n=16)\end{array}$ & $\begin{array}{l}\text { Master's } \\
I \text { and II } \\
(n=66)\end{array}$ & $\begin{array}{c}\text { Baccalaureate } \\
\text { I and II } \\
(n=70)\end{array}$ & $\begin{array}{l}\text { Associate } \\
(n=30)\end{array}$ & $\begin{array}{c}\text { Total } \\
(n=255)\end{array}$ \\
\hline \multicolumn{7}{|c|}{ Tenure clock stop } \\
\hline Formal & $86 \%$ & $44 \%$ & $32 \%$ & $23 \%$ & $7 \%$ & $43 \%$ \\
\hline Informal & 4 & 13 & 6 & 9 & 0 & 6 \\
\hline No policy & 10 & 43 & 62 & 68 & 93 & 51 \\
\hline \multicolumn{7}{|c|}{ Modified duties } \\
\hline Formal & 32 & 13 & 12 & 17 & 3 & 18 \\
\hline Informal & 6 & 0 & 3 & 19 & 7 & 8 \\
\hline No policy & 62 & 87 & 85 & 64 & 90 & 74 \\
\hline \multicolumn{7}{|c|}{ Paid dependent care } \\
\hline Formal & 22 & 6 & 15 & 16 & 7 & 16 \\
\hline Informal & 1 & 0 & 2 & 9 & 3 & 4 \\
\hline No policy & 77 & 94 & 83 & 75 & 90 & 80 \\
\hline \multicolumn{7}{|c|}{ Unpaid leave beyond FMLA } \\
\hline Formal & 53 & 44 & 39 & 24 & 43 & 40 \\
\hline Informal & 12 & 6 & 15 & 9 & 10 & 11 \\
\hline No policy & 35 & 50 & 46 & 67 & 47 & 49 \\
\hline \multicolumn{7}{|c|}{ Reduced appointment, extraordinary needs } \\
\hline Formal & 29 & 19 & 9 & 7 & 7 & 15 \\
\hline Informal & 0 & 0 & 0 & 0 & 0 & 0 \\
\hline No policy & 71 & 81 & 91 & 93 & 93 & 85 \\
\hline \multicolumn{7}{|c|}{ Reduced appointment, ordinary needs } \\
\hline Formal & 29 & 6 & 9 & 6 & 7 & 13 \\
\hline Informal & 12 & 13 & 15 & 17 & 17 & 15 \\
\hline No policy & 59 & 81 & 76 & 77 & 76 & 72 \\
\hline \multicolumn{7}{|c|}{ Part time/job share } \\
\hline Formal & 23 & 6 & 9 & 13 & 7 & 14 \\
\hline Informal & 0 & 0 & 0 & 0 & 0 & 0 \\
\hline No policy & 77 & 94 & 91 & 87 & 93 & 86 \\
\hline \multicolumn{7}{|c|}{ Employment assistance } \\
\hline Formal & 25 & 0 & 3 & 3 & 0 & 9 \\
\hline Informal & 43 & 19 & 14 & 16 & 10 & 22 \\
\hline No policy & 32 & 81 & 83 & 81 & 90 & 69 \\
\hline
\end{tabular}

the survey, we found that research faculty were one-third to one-half as likely as their colleagues to be eligible to use these policies.

Formal versus Informal Policy. Respondents were asked to specify whether institution-wide policies were formal and written or informal and based on individual arrangements. (See Table 3.3.) Not surprisingly, we discovered that the research institutions, which are often more complex and 
have greater resources, were more likely than other Carnegie types to have formalized policies.

Our survey did not ask about the formal or informal nature of policies providing paid time off for recovery from childbirth. This is because the Pregnancy Discrimination Act of 1978 requires institutions to provide paid time off for pregnancy and childbirth if they provide paid time off for other forms of illness or disability. Given this requirement, we assumed the majority of paid leave policies for recovery following pregnancy would be formal.

Dependents for Whom Work/Family Policies Can Be Used. We sought to determine whether institutions made their work/family policies available to faculty to different degrees, based on the type of dependent needing care. We also questioned whether institutions attempt to be gender blind in their application of policy for faculty with dependent care needs. For each policy relating to dependent care needs, we asked, "For what types of dependents may a faculty member take X policy?" Respondents could choose any or all of the following answer choices:

- A woman faculty member may use the policy if she is pregnant or gives birth to a child.

- A man or woman faculty member may use the policy if a child is born into the household.

- A man or woman faculty member may use the policy if a child is adopted or fostered into the household.

- A man or woman faculty member may use the policy to care for an adult or child who is ill, injured, or disabled.

Results on this measure of eligibility are detailed below.

Tenure Clock Stop. Of all the policies examined in this study, the one provided most often was tenure clock stop. When analyzed in terms of the types of dependents for whom a faculty member could request a tenure stop, we found that master's and baccalaureate institutions were less likely to make this policy available to male faculty who had a child born into the household than they were to a woman faculty member who gave birth. Research, doctoral, and Associate degree institutions, however, took a more gender-blind approach to this policy by offering it to both women and men equally.

It should be noted that cost was the barrier most often cited by institutions to the implementation of work/family leave policy in Friedman, Rimsky, and Johnson's 1996 study. But while tenure clock stop might bear an opportunity cost for the individual, it bears no direct cost for the institution. As might be expected, tenure clock stop policies have the strongest showing at institutions where research and original scholarship are core institutional missions and are critical to tenure achievement.

Modified Duties Leave. Overall, 18 percent of institutions carried a formal modified duties policy, although it is noteworthy that percentages were closer to one-third for the research institutions and zero for the 
Associate degree colleges. Modified duties policies were more likely to be provided to women faculty who give birth than for other dependent care reasons.

Unpaid Dependent Care Leave in Excess of FMLA. Not surprisingly, universities offer their faculty unpaid leaves to a much greater extent than paid leaves. Forty percent of the sample reported having a formal institution-wide policy offering more than the twelve weeks of unpaid dependent care leave required under FMLA. Research institutions were somewhat more likely to have unpaid dependent care leave beyond FMLA than were other types of institutions.

Respondents were asked to indicate the maximum number of days or weeks offered by their policies (beyond FMLA), whether the amount of leave was negotiable, or whether it would be determined in some other fashion. Sixty percent of respondents indicated the amount of leave was negotiable, 23 percent provided "other" responses, and 17 percent indicated a specific number of days or weeks. Among this 17 percent, the maximum number of days offered beyond FMLA was fairly evenly distributed across a range of between 1 and 364 days.

Paid Dependent Care Leave. Sixteen percent of respondents reported having formal institution-wide policies for paid dependent care leave. Institutions tended to offer this policy to both women and men faculty with newborns more often than to women childbearers exclusively.

While unpaid dependent care leave in excess of FMLA is an important barometer of where institutions stand with respect to federal standards, the literature (Han and Waldfogel, 2003) and common sense indicate that paid leaves have much greater impact on employees' lives. Given the cost of paid leaves at the institutional level, it is not surprising that they are found less frequently than are unpaid dependent care leaves. Our findings corroborate the assertion that "institutions with larger budgets and larger student bodies are more likely to offer family-friendly programs and policies" (Friedman, Rimsky, and Johnson, 1996, p. 2).

Reduced, Part-Time, and Job-Share Appointments. Only 14 percent of the sample reported having formal, institution-wide policies that gave employees access to reduced appointments for extraordinary reasons such as the severe illness of a dependent. In the case of reduced appointments for ordinary reasons, such as a desire to spend more time at home with a young child, 13 percent of the sample reported the existence of formal, institution-wide policies. In the case of appointments that were offered as part-time or job share, 14 percent of the sample reported the existence of formal, institution-wide policies supporting such positions. For all three policies, research institutions were the most likely of all Carnegie types to offer these options.

We found it noteworthy that 15 percent of institutions had an informal, institution-wide policy of allowing reduced appointments in response to ordinary needs. For extraordinary reasons, however, there were no institutions 


\section{Table 3.4. Methods of Providing Paid Childbirth-Related Time Off by Institution Type}

\begin{tabular}{lcccccc}
\hline & $\begin{array}{c}\text { Research } \\
\text { I and II } \\
(n=73)\end{array}$ & $\begin{array}{c}\text { Doctoral } \\
\text { I and II } \\
(n=16)\end{array}$ & $\begin{array}{c}\text { Master's } \\
\text { I and II } \\
(n=66)\end{array}$ & $\begin{array}{c}\text { Baccalaureate } \\
\text { I and II } \\
(n=70)\end{array}$ & $\begin{array}{c}\text { Associate } \\
(n=30)\end{array}$ & $\begin{array}{c}\text { Total } \\
(n=255)\end{array}$ \\
\hline Policy & $77 \%$ & $56 \%$ & $79 \%$ & $47 \%$ & $90 \%$ & $69 \%$ \\
Sick leave & 51 & 50 & 44 & 37 & 33 & 43 \\
$\begin{array}{l}\text { Disability leave } \\
\text { Vacation leave }\end{array}$ & 51 & 31 & 36 & 17 & 43 & 36 \\
$\begin{array}{c}\text { Maternity leave } \\
\quad \text { distinct from }\end{array}$ & & & & & & \\
$\quad \begin{array}{l}\text { sick, vacation, } \\
\text { or disability) }\end{array}$ & 34 & 6 & 17 & 34 & 10 & 25 \\
$\begin{array}{c}\text { Temporary relief } \\
\text { from teaching, } \\
\text { modified duties }\end{array}$ & 55 & 44 & 26 & 49 & 17 & 40 \\
\begin{tabular}{c} 
Other \\
\hline
\end{tabular} & 36 & 13 & 21 & 11 & 13 & 21 \\
\hline
\end{tabular}

Note: Respondents could choose more than one method. Therefore, percentages total more than 100 .

that had informal, institution-wide policies. With the exception of employment assistance for spouses or partners, reduced appointments were more likely than any other policy to be offered through informal mechanisms.

Employment Assistance for Spouses or Partners of Faculty. Fewer than 10 percent of the sample reported the existence of formal employment assistance programs for faculty spouses or partners; however, 22 percent indicated that such assistance was available on an informal basis. Formal dual-career programs were almost exclusively found within research institutions; one-fourth reported having them.

Methods of Providing Paid Leave Following Childbirth. Nearly 70 percent of schools reported providing childbirth-related leave in the form of sick leave. The second most common method was disability leave (43 percent), followed by 36 percent offering vacation leave. On average, only a quarter of the schools in the sample provided women with a paid maternity leave. Although survey language for the fourth category was "temporary relief from teaching or other modification of a faculty member's duties for one term or longer," data from the telephone survey lead us to believe that respondents may have chosen this response even if relief was given for less than one term in length. For example, respondents may have chosen this method of leave to reflect coverage of some of a faculty member's class sessions by colleagues. (See Table 3.4.)

Among colleges selecting "other" as one method of providing paid childbirth-related benefits, 20 percent wrote in unpaid leaves such as FMLA, displaying a lack of understanding of the paid leave definition used in the question. Alternative policies colleges described for their "other" responses were parental, personal, or family leaves; medical 
leaves; banking of courses by the faculty member in advance of her or his need for time off; and colleague coverage of the faculty member's classes. About 10 percent of "other" responses explained how the institution's disability coverage applied to pregnancy.

Faculty Unions. Overall, instructional faculty were more likely to be unionized than research faculty. Twenty-two percent of our Web survey respondents had unionized instructional faculty, with 7 percent of those also having unionized research faculty. None of our respondents had unionized research faculty without also having unionized instructional faculty. Of our fifty-one telephone survey respondents, fourteen (27 percent) had unionized instructional faculty. Five of the fourteen also had unionized research faculty.

The existence of a faculty union correlated with an increased chance of having certain types of formal policies among research and master's institutions. Our Web survey found that unionized master's institutions were more likely than nonunionized master's institutions to have formal policies for tenure clock stops, modified duties, and unpaid leave in excess of the twelve weeks required by FMLA. Unionized research universities were more likely than their nonunionized peers to have these policies, as well as formal policies for reduced or part-time appointments and job-sharing arrangements from the date of hire.

\section{The Telephone Interview}

We conducted telephone interviews with a subset of Web survey respondents in order to measure faculty members' use of policies, the conditions or limits applied to their use, and the factors that encouraged or discouraged policy development and use. During the interview, we asked respondents, most of them provosts or associate provosts, questions such as:

- To what extent are work/family policies used by faculty? If the rate of use is particularly low or high, why might that be?

- What types of environments and actors have facilitated the development and implementation of work/family policies?

- What barriers exist to the creation of new family-friendly policies?

We found that the one-to-one conversation of the telephone survey allowed us to gather a rich sense of the ways policies are enacted and perceived, thus complementing the purely institutional data gathered from the Web-based survey. With the telephone data, our study is able to provide the kind of strategic guidance that university administrators need as they work to develop a healthy work-life environment for new and existing faculty within their institutions.

The telephone survey participants represented the following institutional types (using the 1994 Carnegie classification): Research I or II, 
twenty-six (51 percent); Doctoral I or II, three ( 6 percent); Master's, eleven (22 percent); Baccalaureate, eight (16 percent); and Associate, three (6 percent).

In our telephone interview, we asked a variety of questions to achieve a sense of policy use by faculty. Administrators were asked two questions specific to women faculty: "What policy or policies is a pregnant faculty member most likely to use for pregnancy and childbirth?" and which "policy or policies women faculty typically use for dependent care needs, after they have recovered from childbirth" but wish to stay home longer with a newborn.

We also asked administrators to estimate how frequently their male or female faculty used any of the family-friendly policies available to them. Respondents were asked to consider only those individuals who would have been eligible to use a policy (for whatever reason) and had the need to do so within the previous year. Estimated use was gauged on a five-point scale from faculty "never" use the policy to faculty "always" use the policy when needed. Interviewers asked only about policies that were formal and offered institution-wide by the respondent's university. We recognize the limitations of administrator-reported utilization estimates.

Use of Sick Time and Disability Leave Following Childbirth. Sick time for pregnancy and childbirth was the only policy for which respondents reported high levels of policy use ("frequent" or "always"). What we learned in our telephone discussions regarding use of sick and disability leaves was quite revealing. Essentially, many institutions think one way about the policies available for recovery from childbirth, but the specific eligibility requirements of those policies may make women childbearers ineligible to use them.

First, although 69 percent of Web respondents said faculty women were able to use sick leave for recovery from childbirth, many of these respondents refuted their Web answers during the telephone interview, saying that only twelve-month faculty were eligible for traditional sick leave. The majority of faculty at these institutions were nine- or ten-month employees.

Second, 43 percent of all Web respondents said women could use disability leave while recovering from childbirth. In the telephone interviews, however, several respondents noted that disability benefits did not begin until the faculty member had been disabled for six or more weeks. Effectively, then, these institutions' paid disability leaves are not available to the majority of women faculty whose medical recovery is completed within six to eight weeks.

While some universities may claim to be compliant with the Pregnancy Discrimination Act within the letter of the law, these data highlight the problem of having practical means by which women faculty can take leave for recovery from childbirth on equal terms with their male counterparts who are recovering from other short-term medical conditions. Even at institutions where a nine-month faculty member does have sick leave benefits and may 
begin using disability leave as needed before or after childbirth, departments may not address coverage of women faculty's teaching responsibilities in the same manner they would for male faculty needing leave for other medical conditions.

Another important issue revealed by our survey was the impact on women retirees' pension and health care benefits. Some institutions expect women faculty to use sick leave while recovering from childbirth. But where faculty are covered by a state benefits system, women are negatively affected if that system rewards unused sick leave days by counting them toward increased pension payouts or reduced retiree health care premium charges.

Unpaid Dependent Care Leave. Only seventeen of thirty-nine respondents to the question said that women commonly used unpaid dependent care leave during their recovery time following childbirth. For women wishing to stay home with a newborn past the time of their own recovery, twenty-one of thirty-eight respondents said women typically relied on unpaid leave. When considered outside the context of childbirth, estimates of the use of unpaid dependent care leave were low, with the vast majority of institutions reporting that faculty "rarely" or only "sometimes" used this policy.

Paid Dependent Care Leave. At the few institutions where paid dependent care leave was offered, this policy generally was said to be used "frequently." Given this policy's focus on dependent care, however, it is not surprising that this policy was reported as not commonly used during women faculty members' recovery from childbirth.

Modified Duties and Tenure Clock Stop. The estimated use by men and women faculty members of both the modified duties and tenure clock stop policies ranged fairly evenly across the spectrum from "never" to "always." This was despite respondents' ranking the modified duties policy as the third most commonly used by women recovering from childbirth and by women wishing to spend more time with their child following their own recovery from childbirth. Tenure clock stop was a policy rarely mentioned as helpful to women recovering from childbirth, but was noted as the fourth most commonly used policy for those staying home with an infant following their own recovery.

Reduced Appointments. All three questions under discussion relating to use indicated that faculty request reduced appointments only "sometimes" and "rarely" in the case of covering time home to recover from childbirth or to be with a new baby after recovery. Reduced appointments were spoken of as more appealing to senior faculty wishing to negotiate a phased retirement.

\section{The Pros and Cons of Gender-Neutral Policies}

The tendency of higher education institutions to enact gender-neutral policy is clearly demonstrated by the low percentage of institutions offering paid maternity leaves as opposed to paid sick or disability leaves. This may 
be because institutions do not want to be perceived as offering women anything more than a medical benefit to cover those weeks when the woman is recovering from childbirth. Some respondents to our telephone interview suggested that having policies constructed to respond to multiple needs (such as personal leave that can be taken for professional, personal, medical, or family needs) made the use of such policies more acceptable to their faculty peers.

Findings from a recent study at the University of Virginia indicate, however, that women, on average, assume more child care and housekeeping activities than their spouses, even when that (male) spouse is in the midst of a dependent care leave (Rhoads and Rhoads, 2003). This raises the question of whether men are more likely than women to use dependent care leaves to accomplish professional rather than family tasks. The implication of this finding is that gender-neutral policies are not necessarily helping women to achieve a level playing field in the academy. If the same leaves women use to recover physically from childbirth, nurse a baby, and contend with lack of sleep can be used by male faculty who have wives at home to care for their newborn child while they work on their research, then these women faculty will fall behind their male peers in terms of productivity.

Some institutions have attempted to protect against such policy abuses by restricting eligibility to faculty with high levels of caregiving responsibilities. Among our fifty-one telephone survey respondents, one-quarter had language in their policies related to dependent care that required the faculty member to be the primary caregiver or a coequal caregiver or to have substantial care responsibilities for the dependent. Twelve percent specifically required the faculty member to provide a statement attesting to this fact.

After discussing policy use with administrators, we asked why they thought faculty did not take advantage of policies more often. Of the thirtysix institutions that answered this question, twelve cited fear of career repercussions as the reason for infrequent policy use. Eleven of the thirty-six said faculty were unable to afford to take unpaid time away from work. Ten institutions suggested that faculty tended not to use these policies because families were able to time the birth of their children to occur over academic breaks or otherwise accommodate family needs through the creative juggling of classes or with support from stay-at-home partners. Nine of the thirty-six respondents said faculty were too committed to their work to take leave, and six said unclear processes hampered faculty's use of policies. These findings suggest areas where universities can focus their attention in order to increase faculty use of family-friendly policies.

\section{Strategies for Successful Policy Development and Use}

A director of academic personnel described his institution's support of work/family policies as deriving from "a consciousness that we needed to be-it was in the university's best interest to be-open to these things." So what do universities do in order to develop, implement, and improve the 
use of their work/family policies for faculty? Our interviews revealed five key strategies:

- Use data to promote a work/family balance agenda.

- Foster collaboration between individual policy champions and institutional committees to ensure successful policy development.

- Formalize policies and make them entitlements.

- Educate faculty and administrators about the policies on a continuous basis.

- Address climate issues that discourage faculty from using work/family policies.

Data. Universities found policy development was much more easily accomplished when data from surveys or other research on the work/family environment were available to bolster their proposals. Seventeen of our fiftyone telephone interview respondents reported their institutions had conducted research on work/family climate for faculty. This research most often took the form of climate surveys; some focused on faculty issues alone, and others addressed both faculty and staff topics. Other research included reviews of institutional data on policy use, exit interviews, policy comparisons with peer institutions, and comparisons of the tenure achievement rates of faculty who stopped the tenure clock versus those who did not.

One institution's story exemplifies the snowball effect that data gathering can inspire. In the early 1990s, a work/family task force of staff and faculty led to creation of a position and a survey. The task force and survey was sponsored by a senior vice president, a male, who was very concerned about these issues. The survey led to other discussions and initiatives. The position spun off from the associate vice president for human relations office into a new human relations office: Workforce Diversity, Equity, and Life Quality.

As we discuss in the following section, champions of work/family issues are often the ones to commission or request such climate surveys in order to raise awareness of faculty needs and elevate the discussion toward potential solutions.

Measurement is also a tool administrators can and should use to guide an institution's progress on work/family objectives. One helpful measure is tracking whether use of the tenure clock stop affects faculty members' tenure achievement. While shockingly few of the institutions in our telephone survey collected these data (only three of fifty-one), many said such information was needed to help address fears among some faculty that using this policy might harm their chances for tenure. Regular comparisons between the tenure achievement rate of policy users and nonusers are fairly simple. These analyses can also be done to discern any differences in tenure achievement by race or gender. Universities typically look at a cohort of assistant professors hired eight or nine years prior and define the current 
status of each faculty member within the cohort within one of four categories: left the university without achieving tenure, achieved tenure, still pending tenure review, or at the university in a non-tenure-track position. We acknowledge that the first category will combine faculty who were denied tenure with those who leave prior to tenure review but may have been expected to achieve tenure. Nevertheless, this is a reasonable measure, as well as one that is achievable under most data systems and one we suggest be done regularly. Some institutions choose to conduct exit interviews of departing faculty in order to clarify the reasons faculty have for leaving prior to tenure review.

Another measure that was seen as valuable, but infrequently done due to the lack of formalized metrics, was feedback on the family friendliness of chairs and deans as part of their annual evaluations. Many institutions said that openness by administrators to their faculty members' use of work/family policies was considered during evaluations, but only in informal ways. More formal means of assessing the work/family climate in a department or school would better hold chairs and deans accountable for the pivotal role they play in shaping the culture within their span of control.

Policy Champions. More than half of our fifty-one telephone interview respondents named their president and provost as actors instrumental in the development of work/family policies for faculty. More than one-third said that deans, committees on the status of women, and faculty senate committees that addressed benefits, diversity, or recruitment and retention played a key role in policy development. Again, more than onethird said that individual faculty members played important roles in spearheading successful policy development on their campuses. As would be expected, human resource offices were described as instrumental in the process of developing work/family policies by two-thirds of the institutions. One-quarter of those surveyed indicated their faculty union was influential in policy development.

We found that the effect of women's involvement in policies extended beyond university committees on the status of women. Twenty-four percent of respondents indicated that women's centers, women's studies programs, and other women's organizations were instrumental in shaping their college's policy deliberations. One respondent described instances in which an individual or committee raised the need for new family-friendly policies as "the process of addressing the squeaky wheel."

Although 84 percent of our telephone survey respondents had units or individuals assigned to help faculty on work/family issues, these work-life resources were not reported to be key contributors to policy development. There was, however, a clear and positive correlation between the degree to which an institution had a variety of formalized policies and the likelihood that it had dedicated work/family resources. We surmise that the existence of such resources is an indicator of an institution's progress toward achieving a comprehensive array of family-friendly policies and services. 
When asked, "What type of development or advocacy efforts led to establishment of work/family policies at your institution?" nearly one-third of those interviewed (sixteen of fifty-one) described a push to ameliorate the tension between parenting and work for faculty women. Thirteen of fifty-one mentioned concerns regarding equitable treatment for women, lesbian or gay faculty, or faculty of color as inspiring action on their campuses. Seven respondents said discussions regarding access and financial support for child care were triggers for advocacy within their institutions. Occasionally work/family policy achievements were accomplished in response to external pressures such as accreditation reviews or lawsuits. In a few cases, discussion regarding the provision of health insurance benefits to domestic partners spurred reflection on the eligibility of gay or lesbian faculty to use work/family policies to care for their domestic partner or the children of their partner.

Formalize Policies and Make Them Entitlements. Many institutions found that formalizing policy simply acknowledged what was already current practice in their schools or departments. Policy formalization raised the visibility of the policy so that both faculty and administrators had a clearer understanding of the rules for policy use. We found that reduced appointments, modified duties, and unpaid leaves were the policies most likely to be informally negotiated.

Having a formal policy on the books increased goodwill among existing faculty and was seen as a recruitment tool for attracting new faculty. It also improved the climate for faculty by acknowledging that most faculty will have a family need to manage at some point during their career, whether for young children, a dying parent, or an ill spouse or partner.

Many colleges found they benefited from outlining the circumstances under which faculty were entitled to use each policy. This relieved individual administrators from having to spend time making highly personal, case-by-case decisions each time a faculty member requested use of a policy. Among the twenty respondents with a formal institution-wide policy providing paid dependent care leave, twelve made this type of leave an entitlement. Among the twelve institutions with a formal institution-wide policy allowing modified duties, four made it an entitlement. Formal policies regarding unpaid dependent care leave in excess of FMLA and reduced appointments were not as likely as other policies to be structured as entitlements.

Of the thirty-nine institutions with a formal institution-wide tenure clock stop policy, fifteen had specific criteria for entitlements. Nine of these fifteen institutions making it an entitlement did so for reasons specific to childbirth, adoption or fostering of a child, or newborn care by a primary caregiver. The other six of these fifteen institutions entitled both male and female faculty to use the tenure clock stop for a broader array of reasons. Of the nine institutions that limited entitlement to women faculty or new children in the home, five had additional policy provisions that made fathers of 
newborns or faculty caring for other types of dependents eligible to request tenure stop, with use granted at the discretion of the administration.

One theme that emerged from our analysis was that the nature of informal leaves and the process of negotiation that they necessitate makes exercise of such policies much less frequent than formalized policies. When institutions formalize policies and entitlement reasons, as one administrator put it, faculty "know the benefits are entitlements and there's no stigma attached" to using them.

Educate Faculty and Administration About the Policies. Institutions need to make sure that information about policies is thoroughly disseminated to all relevant constituencies. Universities used new faculty orientations, information sessions for deans and chairs, their faculty handbooks, and Web sites as their main methods for policy education. Some institutions also use existing faculty and administrative forums to remind audiences of family-friendly policies and address perceptions about their costs and benefits. Brochures and programs on work/family balance are other avenues colleges use to promote the availability of policies for faculty.

Frequent sharing of policy information is critical for many reasons, including the regular turnover among department chairs and the addition of new faculty. Furthermore, not all faculty members will need information about family-friendly policies at orientation, yet many may require it later when they are expecting a child or are presented with an elder care crisis. Periodic communication of work/family information allows faculty members and administrators to be aware of the latest university offerings. Faculty are more likely to use policies that are well advertised and less likely to be resentful of administrators if they need to use a family-friendly policy but fail to request it because they were unaware of its existence.

Address Climate Issues. Many of those responding to our telephone survey reported that a "chilly climate" sometimes discourages faculty from taking advantage of work/family policies. Twelve of thirty-six respondents cited faculty members' fear of possible career repercussions as the reason work/family policies were not used as often as they might be. Other respondents raised climate concerns in the context of answering other questions during the interview. We believe that every institution needs to address climate issues, whether that institution is seeking to develop its first work/family policies or to create an environment in which faculty feel safe using existing ones.

Some administrators referenced "workaholic" cultures in certain departments or schools where a colleague's family leave might be characterized as showing a lack of professionalism or a willingness to shift burdens onto one's colleagues. In such environments, faculty were said to feel pressure to come back and cover their classes. One respondent noted that "untenured faculty say 'I'm afraid how my colleagues will react to my taking leave.' Even the notion of getting pregnant makes many fear not getting tenure." The respondent described this as a "cultural belief," held by both 
men and women, that taking leave is "inappropriate behavior" and thus likely to affect the tenure outcome. A male human resource director at another institution used these terms to describe reactions in a particular school to faculty taking family leave: "Treatment doesn't vary in terms of official responses that rise to the HR level. But there is a subtle variance or pressure at the department or dean's level. 'You are not here, and everybody else is."

Many we interviewed noted that use of these policies was not well received in traditionally male-dominated departments, such as engineering, business, and the sciences. "Women are watched more in terms of how they fit in," commented one respondent from a research university. Another noted, "It has to do with the discipline and the respect for women in those disciplines. Where there's a critical mass [of women], there's more likely to be a difference." A male assistant provost from another research university described climate issues this way:

The cultures and traditions in the departments, as well as the balance of faculty (percent male to female), will affect [policy] usage. Historically male departments affect informal word of mouth and things you should pay attention to. The role of chair is very important. If very supportive of policies, you will see more use of the policies. If in a rotating position, or not willing, you could see a different result. You hear apocryphal tales that so-and-so didn't use leave because a senior male in her department would frown on it. This does occur in some cases.

However, such beliefs were no longer described as monolithic, but remain in isolated areas of the university. One of our telephone survey respondents cogently described the changing perceptions within academia about women's professional roles and men's parenting roles: "As more women move into faculty ranks, family issues come to the fore and we respond to them. Also, male expectations about coparenting are incredibly different from twenty years ago. Society influences demand [for work/ family policies]."

Leaders within higher education are increasingly called on to manage the impact of this cultural change as it affects their institutions. Management of these different cultural views also requires sensitivity to competing views by age cohorts. We learned that some senior women faculty, having struggled to survive in academia without a supportive work/family environment, sometimes project the same "pull yourself up by your bootstraps" attitudes as their male peers. Having succeeded in their own professional life, sometimes by forgoing a spouse or partner or children to do so, they are resistant to work/family accommodations suggested for junior faculty. Nevertheless, one preeminent research university noted having managers who want to use their institutional position as a source of culture change: "We are particularly concerned about the culture at the graduate level. This 
is the point where people formulate their understanding of what sacrifices are made [to succeed in academia]." This attention to culture as it affects the future pipeline of faculty is one example of what makes this institution a leader among research universities.

At universities where an institutional champion advocated for improved balance between work and family responsibilities, respondents characterized the environment as genuinely responsive to professional and personal needs. When positive statements about work/family balance are made by the president or provost or voiced in departmental, dean, or faculty meetings, this can shape an institution's culture to be more accepting of all faculty members' needs. Chairs and deans play an important role in shaping attitudes about the academic value of faculty with family responsibilities when they make it clear to tenure and promotion committees that faculty must not be penalized for using university policies. Indeed, it is clear that individual leadership makes a difference.

Self-interest and the bottom line were mentioned by respondents as part of the reason their leadership was instituting family-friendly policies for faculty. Universities reported that when work/family policies were used, they often inspired loyalty and a sense of community among faculty. As an associate provost at one research university told us, "It's not just altruism. We do things to keep our faculty." Another research university's associate provost pointed to work/family policies and their impact on retention when she noted that some junior women faculty are prepared to say, "I'm not going to be at an institution if they're going to hold it against me for stopping the tenure clock."

Those surveyed indicated that good feelings not only go a long way toward improving retention rates, but are also evident to prospective faculty who come for recruitment visits. Quite often, the demand to recruit new faculty drove creation of work/family policies, and therefore the cost to offer the policies has been considered part of an institution's recruitment expenditures. More and more, competition for talented young faculty is driving universities to improve their portfolio of family-friendly policies and programs.

Gay and Lesbian Faculty. From our interviews, it is clear that the design of work/family policies applicable to gay and lesbian faculty is the next frontier for many colleges and universities. When asked what policy development efforts were currently under way at their institutions, nearly one-quarter of those responding (eight of thirty-four) mentioned domestic partner insurance benefits or clarifications in policy regarding the eligibility of gay and lesbian faculty. In some cases, policy revisions were due to changes in state law; other cases were driven by changes in university health insurance coverage.

It is important to note that language clearly making gay and lesbian faculty eligible to use work/family policies to care for their domestic partners is still the exception, not the rule. We were surprised to find that institutions 
considered heterosexual partners within their definitions of "domestic partners" almost as frequently as they included same-sex partners. A number of those surveyed mentioned using purposely vague language, such as "persons residing within your household," in order to be able to interpret their policies as applicable to gays and lesbians without antagonizing constituencies who oppose gay rights.

Other Current Initiatives. Other initiatives under development at respondent institutions included campus-based child care programs, spousal hiring programs, and efforts related to tenure. Specific tenure initiatives involved creation of a phased retirement program that would allow senior faculty to retain their tenure status, allowance for a tenure clock stop while faculty work part time, a review of the tenure evaluation process, and an examination of the feasibility of having part-time tenure-track positions.

\section{Opposition to Work/Family Policies}

When respondents were asked where resistance to work/family policy came from, their answers often varied depending on which policy was being considered. Six respondents reported that faculty, unions, or executive officers had concerns about who was able to benefit from the proposed policy and who was not. The type of policy most often debated in these contexts was maternity or paternity leave. While one respondent couched this resistance in terms of "equity," the rest of these responses disaggregated quite clearly along gender lines. For example, resistance to maternity or paternity leaves was said to emerge "from subcultures in the university that are maledominated and senior in age and experience. This impacts informally in terms of expectations in departments and in governance committee deliberations in which they argue for fair treatment (e.g., single individual versus family for insurance premiums)."

A related but more passive form of resistance was evidenced by reluctance to institutionalize work/family policy. The argument for case-by-case application (observed in the example above and in other cases) was usually articulated in conjunction with the perception that work/family policies were of benefit only to women.

Domestic partnership benefits were the policy most often cited as the site of resistance to work/family policy. Six institutions specifically mentioned difficulty getting approval for domestic partnership benefits from their boards of trustees or regents. In several cases, it was noted that the state legislature pressured the board not to ratify these policies. In one instance, action was being taken against the board by the state legislature as a retaliatory measure for approval of domestic partnership benefits.

Funding constraints were often cited as the source of generalized resistance to work/family policy. This view was reinforced by other information we received from our Web survey respondents, many of whom 
were considering new or expanded policies at the time of the survey. When contacted within a year for the telephone interview, most said that budget cutbacks had forestalled any new developments. During the telephone interview regarding opposition to work/family policies, two respondents from public institutions mentioned a zero-sum budget mentality at their institutions, where any discussion of new programs was framed in the context of having to take away from existing programs.

In one case, however, the respondent felt that the institution's focus on budget was simply used as an excuse for inaction. This view is supported by information from another question in the telephone survey, in which respondents were asked if additional money was available to help departments cover the replacement costs for the teaching or other duties of a faculty member on leave. Forty-nine percent of respondents (twenty-five of fifty-one) said additional funding was available to assist departments, often coming from the provost or from some other central budget.

\section{Recommendations for Further Study}

Our study broached the surface of several topics worthy of research in greater depth. In particular, we would like to understand the reasons that elite baccalaureate institutions have nearly as many family-friendly policies as research universities, surpassing all other Carnegie types. Such a study could address our hypothesis that competition with research universities for quality faculty is a major driver for policy development by the elite baccalaureate institutions.

Another area deserving of further study is whether faculty who use work/family policies are any less likely to achieve tenure than faculty who do not use them. Cohort analyses of faculty tenure achievement are relatively simple to conduct. Especially if combined with exit interviews, a tenure achievement study done at a number of institutions would provide clear data to either affirm or allay faculty fears about the potential career repercussions of policy use.

In a similar vein, we recommend studies of the impact on tenure achievement of reduced faculty appointments. Anecdotal evidence suggests that women sometimes move from tenure-track to non-tenure-track positions in order to balance their academic career with the needs of young children. It is unclear whether this movement is often required by university policy or climate or made by choice. Our study demonstrated that colleges do not yet have formal policies that allow reduced appointments for such ordinary dependent care reasons. It would be illustrative to know the degree to which institutional policies mandate movement off the tenure track for regular faculty who are not near the age of retirement but wish to hold parttime appointments. 


\section{References}

American Association of University Professors. "Statement of Principles on Family Responsibilities and Academic Work." 2001. www.aaup.org/statements/reports/ re0lfam.htm.

Cramer, E., and Boyd, J. "The Tenure Track and the Parent Track: A Road Guide." Wilson Library Bulletin, 1995, 65, 41-42.

Drago, R., and Williams, J. "A Half-Time Tenure Track Proposal.” Change, 2000, 32(6), $46-51$.

Friedman, D. E., Rimsky, C., and Johnson, A. A. College and University Reference Guide to Work/Family Programs. New York: Families and Work Institute, 1996.

Galinsky, E., Friedman, D., and Hernandez, C. The Corporate Reference Guide to WorkFamily Programs. New York: Families and Work Institute, 1991.

Glazer-Raymo, J. Shattering the Myths: Women in Academe. Baltimore, Md.: Johns Hopkins University Press, 1999.

Han, W. J., and Waldfogel, J. "Parental Leave: The Impact of Recent Legislation on Parents' Leave Taking." Demography, 2003, 40(1), 191-200.

Hochschild, A. The Second Shift: Working Parents and the Revolution at Home. New York: Viking, 1989.

Holcomb, V. Why Americans Need Family Leave Benefits. Washington, D.C.: National Partnership for Women and Families, 2001.

Hollenshead, C., and others. Women at the University of Michigan: A Statistical Report on the Status of Women Students, Staff and Faculty on the Ann Arbor Campus. (4th ed.) Ann Arbor: University of Michigan, President's Advisory Commission on Women's Issues, 2003.

Kumar, K. "Cultural Diversity's Impact on Group Process and Performance." In C.J.G. Gersick (ed.), Group Management: Current Issues in Practice and Research. Brookfield, Vt.: Dartmouth, 1995.

Leslie, D. W., and Walke, J. "Out of the Ordinary: The Anomalous Academic." 2001. http://www.wm.edu/edu/education/Faculty/Leslie/anomacad.html.

Mason, M. A., and Goulden, M. "Do Babies Matter? The Effect of Family Formation on the Lifelong Careers of Academic Men and Women." Academe, 2002, 6, 21-27.

Rhoads, S., and Rhoads, C. "Gender Roles and Gender-Neutral Post-Birth Policies." Paper presented at the American Association for Higher Education, Washington, D.C., Mar. 16, 2003.

Wilson, R. "A Push to Help New Parents Prepare for Tenure Reviews." Chronicle of Higher Education, Nov. 9, 2001, p. A10. 
CAROL S. HOLlENSHEAD is director of the Center for the Education of Women and chair of the President's Advisory Commission on Women's Issues, both at the University of Michigan.

BETH SULLIVAN is program manager for policy and advocacy at the Center for the Education of Women, University of Michigan.

GILIA C. SMITH is a graduate researcher at the Center for the Education of Women, University of Michigan.

LOUISE AUGUST is a graduate researcher at the Center for the Education of Women, University of Michigan.

SUSAN HAMILTON is a graduate researcher at the Center for the Education of Women, University of Michigan. 